\title{
Occurrence of Conepatus chinga (Molina) (Mammalia, Carnivora, Mustelidae) and other terrestrial mammals in the Serra do Mar, Paraná, Brazil
}

\author{
Nilton C. Cáceres \\ Departamento de Biologia, Centro de Ciências Naturais e Exatas, Universidade Federal de Santa Maria. Faixa Camobi Km 9, \\ 97105-900, Santa Maria, Rio Grande do Sul, Brasil.E-mail: nc_caceres@hotmail.com
}

\begin{abstract}
In this paper 19 additional mammalian species are reported in the Atlantic forest of the Paranean Serra do Mar, southern Brazil, including threatened and rare species. These findings resulted from a one-year field research in the western slope of the Serra do Mar, Piraquara municipality, with additional review of reports about mammal distribution in the region. Preliminarily mammal richness in the region is round 54 species, but this number could be higher with more systematic surveys, particularly with regards to bats. The occurrence of the hog-nosed skunk, Conepatus chinga (Molina, 1782), is reported for the first time in the eastern portion of Paraná, a State vastly deforested during the last century in Brazil.

KEY WORDS. Atlantic forest, conservation, first record, mammalian species.
\end{abstract}

RESUMO. Neste artigo, 19 espécies adicionais de mamíferos são informadas para a Floresta Atlântica da Serra do Mar paranaense, sul do Brasil, incluindo espécies ameaçadas e raras. Este relato é resultado de uma pesquisa de campo de um ano na vertente oeste da Serra do Mar, município de Piraquara, com revisão adicional de relatos sobre a distribuição de mamíferos na região. A riqueza preliminar de mamíferos na Serra do Mar paranaense é de 54 espécies, mas este número poderá aumentar quando mais inventários faunísticos forem realizados, principalmente para morcegos. A ocorrência do cangambá, Conepatus chinga (Molina, 1782), é relatada pela primeira vez na porção leste do Paraná, um Estado altamente desflorestado neste último século no Brasil.

PALAVRAS CHAVE. Conservação, Floresta Atlântica, mamíferos, primeiro registro.

The Paraná State has suffered a high rate of deforestation in the last century, little remaining of the dense and mixed ombrophyllous forests, formerly widely distributed in the State (MAACK 1981). The two main forest remnants occur today in the extreme southwest (Iguaçu National Park) and east (Área de Especial Interesse Turístico do Marumbi - AEIT Marumbi, with 66,700 ha, located near the comprehensive Environmental Protection Area of Guaraqueçaba with 346,000 ha; Paraná 1986) of the State, and are covered mainly by semideciduous seasonal and dense forests, respectively (IBGE 1992). However, little is still known about mammals occurring in these two large protected remnants. A one-year study conducted in the AEIT Marumbi aimed at researching the diet of didelphid marsupials, but generated data on the occurrence of other mammals in the region.

The study area is located at the east edge of the SANEPAR's dam, at coordinates $25^{\circ} 28^{\prime} \mathrm{S}$ and $48^{\circ} 50^{\prime} \mathrm{W}$ and 1,000 $\mathrm{m}$ a.s.l., in the Piraquara municipality, Paraná, commonly known as "Mananciais da Serra" (Rio Iguaçu basin). This area is in the western slope of the Serra do Mar mountains. The area is covered with submontane dense ombrophyllous forest (20 to 25 m of canopy height) but also comprising of mixed ombrophyllous forest species (V.A.O. DiтTRICH, personal communication) due to the proximity of this biome at the western plateau (round $900 \mathrm{~m}$ a.s.l.).

The study was carried out from October 1997 to September 1998 in a 2.2 ha-grid area for small mammals, where 40 traps (baited with banana and codfish liver oil) were set for four consecutive nights, once a month. Large and median mammal tracks, besides direct observations, were searched in the vicinities of the grid area during the overall study period.

Species names follow Fonseca et al. (1996). Voucher small mammal specimens were deposited in the Museu de História Natural Capão da Imbuia at Curitiba (most specimens) and in the Museu Nacional in Rio de Janeiro (Oryzomys ratticeps (Hensel, 1873)), Brazil.

Species trapped (T), directly observed by the author (D), detected by hairs $(\mathrm{H})$ or tracks left $(\mathrm{K})$, and by interviews with local researchers (I) are listed below: Akodon serrensis Thomas, $1902(2 \mathrm{~N}=46)(\mathrm{T})$, Delomys dorsalis (Hensel, 1872) $(\mathrm{T})$, Oryzomys ratticeps (Hensel, 1873) (T), Thaptomys nigrita (Lichtenstein, 1829) (T), Oligoryzomys sp. (Waterhouse, 1837) (T) (Muridae), 
Sciurus aestuans Linnaeus, 1766 (D) (Sciuridae), Myocastor coypus (Molina, 1782) (I) (Myocastoridae), Hydrochaeris hydrochaeris (Linnaeus, 1766) (I), (Hydrochaeridae, Rodentia); Didelphis aurita Wied-Neuwied, 1826 (H, I), Philander frenatus (Olfers, 1818) (T) (Didelphidae, Didelphimorphia); Cebus apella (Linnaeus, 1758) (D) (Cebidae, Primates); Pecari tajacu (Linnaeus, 1758) (I) (Tayassuidae, Artiodactyla); Nasua nasua (Linnaeus, 1766) (D) (Procyonidae), Eira barbara (Linnaeus, 1758) (I), Galictis cuja (Molina, 1782) (I), Conepatus chinga (Molina, 1782) (D) (Mustelidae); Cerdocyon thous (Linnaeus, 1766) (K) (Canidae), Leopardus spp. (K, I), and Puma concolor (Linnaeus, 1771) (K) (Felidae, Carnivora). The Oligoryzomys species is most probably O. flavescens (Waterhouse, 1837), based on general characters, small size and arboreal habit.

According to these data and previous surveys (THомAs 1902, Margarido et al. 1997, LANGe \& JABLONSKI 1998), at least 54 mammalian species are known to occur in the Paranean Serra do Mar, even at unprotected areas. These include common small mammal species easily trapped in the eastern portion of the Serra do Mar such as the rodents Nectomys squamipes (Brants, 1827) and Oryzomys russatus (Hensel, 1873) (personal observation). Based on additional data (Bergallo et al. 1998, LANGe \& Jablonski 1998, Eisenberg \& Redford 1999, De Vivo \& Gregorin 2001), mammals occurring in surrounding regions, such as the rodents Rhipidomys mastacalis (Lund, 1840) and Kannabateomys amblyonyx (Wagner, 1845), the marsupials Chironectes minimus (Zimmermann, 1780), Caluromys philander (Linnaeus, 1758) and Metachirus nudicaudatus (Desmarest, 1817), and several bat species, are expected to occur in the Serra do Mar of Paraná State. This list should increase much more (see DE VIVo \& GREGORIN (2001) for an adjacent area) when systematic mammal surveys are carried out in the region, particularly for bats.

Concerning the occurrence of the hog-nosed skunk $C$. chinga, this report is thought to be the first for the Paraná State. This occurrence was registered in July 1998 in the study area (trap grid and camp), with additional evidence in September 1998. The animal had the following characteristics: white stain in the head top; black-brownish flanks and tail; erect and semicoiled upward tail.

FONSECA et al. (1996) listed only C. chinga as occurring in the Atlantic forest (see also Emmons \& Feer 1997), being $C$. semistriatus (Boddaert, 1784) restricted to the Caatinga and Cerrado (see also Cabrera 1957, Carvalho 1983, Eisenberg \& REDFoRD 1999). Distribution records of C. chinga around Paraná State are available according to CARvalHo (1979): Franca and Santa Rita do Passa Quatro municipalities - São Paulo, Rio Grande basin; Cimardi (1996): Blumenau, Pouso Redondo, Bom Retiro and Lages municipalities - Rio Itajaí-Açu and Rio Uruguai basins (Fig. 1). The occurrence of $C$. chinga at Blumenau (Santa Catarina) and Intervales (São Paulo - De VIVo \& Gregorin 2001) are the shortest distances from the locality of the current report $(<160 \mathrm{~km})$, showing an apparent continuous distribution along Serra do Mar (Fig. 1). Chebez (1996) also found $C$.

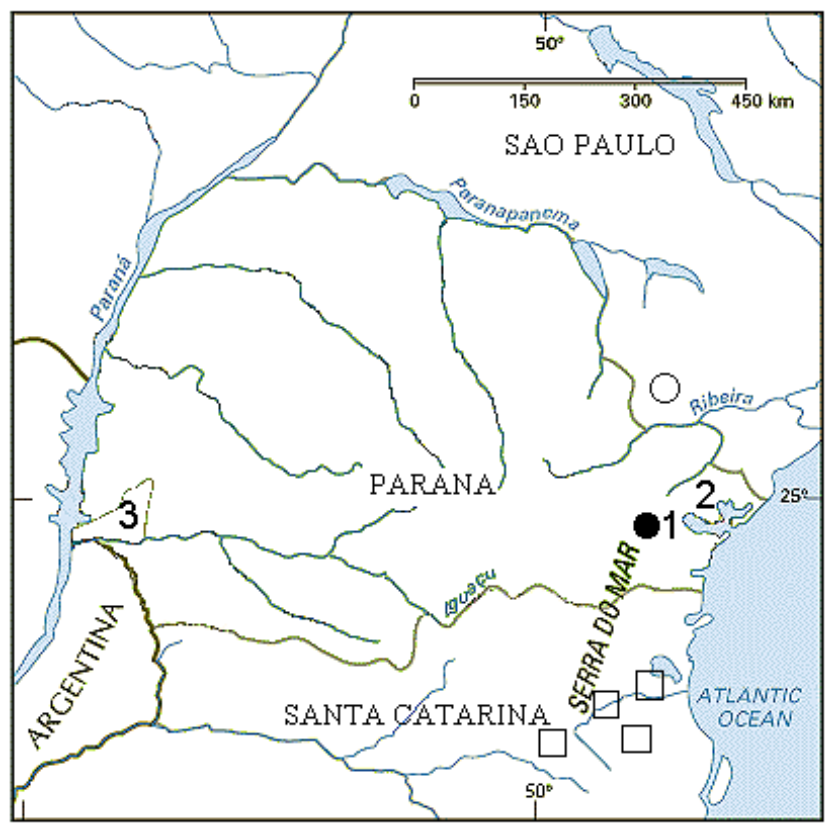

Figure 1. Localities where the hog-nosed skunk, Conepatus chinga, have been reported in south Brazil. SãoPaulo (De VIVo \& GREGorIN 2001): at south São Paulo (O); Paraná (this report): (•) at eastern Paraná; Santa Catarina (CIMARDI 1996): for four localities ( $\square$ ) at eastern Santa Catarina. Numbers indicate comprehensive reserves in the Paraná State: (1) AEIT Marumbi, (2) Environmental Protection Area of Guaraqueçaba, (3) Iguaçu National Park.

chinga in south Missiones, northern Argentina. A revision of the distribution of Conepatus species is needed to determine geographical limits of South American species (see VIEIRA 1946, 1955, Emmons \& FeER 1997).

Today little can be known about the actual distributions of skunk species because the broad deforestation that occurred in south and southwestern Brazil during the last century (e.g. MaACK 1981, Fonseca 1985). Due to this, some open-habitatdwelling mammalian species such as the giant anteater (Myrmecophaga tridactyla Linnaeus, 1758 (Myrmecophagidae)) and the maned wolf (Chrysocyon brachyurus (Illiger, 1815) (Canidae)) appear to live in forest edges as well, in response to this disturbance (J. QuADRos, personal communication) in the Paraná State, as it seems to be the case for the hog-nosed skunk (sensu Emmons \& FeER 1997, p.161).

The Serra do Mar of Paraná is important because is one of the largest Atlantic Forest remnant in Brazil (more than 380,000 ha - PARANÁ 1986), in connectivity with submontane forests of São Paulo to the north and Santa Catarina to the south. The presence of mammals such as the puma (P. concolor) and the hog-nosed skunk, as well as other vertebrate species such as the robust woodpecker Campephilus robustus (Lichtenstein, 1819) (Picidae, Aves) and the snake Attractus 
maculatus (Colubridae, Reptilia) in the study area (personal observation), points out to the importance of this region for conservation, even though these species are rare (J.C. MourALeite, personal communication for A. maculatus) or even (near) threatened (for $P$. concolor and Leopardus species) according the World Union for Conservation (IUCN) and the Brazilian Institute for Environment (IвамA).

\section{ACKNOWLEDGEMENTS}

The author thanks J.A. Oliveira, I.J. Sbalqueiro and A.P. Carmignoto for help in the rodent identifications, M. Pichorim for help in the woodpecker identification, J. Quadros for the hair identification, B. Palacio for the English revision, and M.R. Bornschein for the incentive furnished to work in the Mananciais da Serra. R.F. Torres and M. Pichorim helped with their field observations of mammal species. T.C.C. Margarido motivated the elaboration of this note. J. Quadros and E.L.A. MonteiroFilho helped with bibliography. I also thank the Companhia de Saneamento do Paraná that supported the present study.

\section{REFERENCES}

Bergallo, H.G.; C.F. Vera y Conde; E.B. Bittencourt; D.E.P. Bossi \& C.F.D. Rосна. 1998. As similaridades nos parâmetros comunitários de pequenos mamíferos de duas áreas de Mata Atlântica do Sul de São Paulo, sudeste do Brasil. In: Anais do VII Seminário Regional de Ecologia, São Carlos: 939-949.

Cabrera, A. 1957. Catálogo de los mamíferos de América del Sur. Revista del Museo Argentino de Ciencias Naturales "Bernardino Rivadavia", Buenos Aires, 4 (1): 1-307.

Carvalho, C.T. 1979. Mamíferos dos parques e reservas de São Paulo. Silvicultura, São Paulo, 13/14: 49-72.

_ 1983. Lista nominal dos mamíferos brasileiros. Boletim do Instituto Florestal, São Paulo, 37: 31-115.

Chebez, J.C. 1996. Fauna missioneira. Buenos Aires, L.O.L.A., $\mathrm{I}+318 \mathrm{p}$.

Cimardi, A.V. 1996. Mamíferos de Santa Catarina. Florianó- polis, FATMA, 302p.

De Vivo, M. de \& R. Gregorin. 2001. Mamíferos, p. 116-123. In: C. LeONEl (Ed.). Intervales. São Paulo, Fundação para a Conservação e a Produção Florestal do Estado de São Paulo, IX+240p.

EISENBERG, J.F. \& K.H. REDFord. 1999. Mammals of the neotropics: the central neotropics. Ecuador, Peru, Bolivia, Brazil. Chicago, University of Chicago Press, X+609p.

EMMONs L.H. \& F. FEer. 1997. Neotropical rainforest mammals: a field guide. Chicago, University of Chicago Press, XVI+ 307.

FonseCA, G.A.B. 1985. The vanishing Brazilian Atlantic forest. Biological Conservation, London, 34: 17-34.

Fonseca G.A.B.; G. Herrmann; Y.L.R. Leite; R.A. Mittermeier; A.B. Rylands \& J.L. Patton. 1996. Lista anotada dos mamíferos do Brasil. Occasional Papers on Conservation Biology, Belo Horizonte, 4: 1-38.

IbGe. 1992. Manual técnico da vegetação brasileira. Rio de Janeiro, IBGE, I+92.

LANGE, R.B. \& E.F. JablonsKi. 1998. Mammalia do Estado do Paraná: Marsupialia. Estudos de Biologia, Curitiba, 43: 15-224.

МАAск, R. 1981. Geografia física do Estado do Paraná. Rio de Janeiro, José Olímpio, I+450p.

Margarido, T.C.C.; L.C.M. Pereira \& P.A. Nicola. 1997. Diagnóstico da mastofauna terrestre na APA de Guaraqueçaba, Paraná - Brasil. In: Anais do I Congresso Brasileiro de Unidades de Conservação, Curitiba: 616-634.

Paraná. 1986. Cadernos do patrimônio: tombamento da Serra do Mar. Série Estudos 3. Curitiba, Secretaria do Estado da Cultura, Governo do Estado do Paraná, 170p.

Thомаs, F.R.S.O. 1902. On mammals of the Serra do Mar of Paraná, collected by Mr. Afonse Robert. Annals and Magazine of Natural History, London, 4 (7): 59-64.

Vieira, C.C. 1946. Carnívoros do Estado de São Paulo. Arquivos de Zoologia, São Paulo, 5 (3): 135-175.

. 1955. Lista remissiva dos mamíferos do Brasil. Arquivos de Zoologia, São Paulo, 8 (11): 341-474.

Received in 15.V.2003; accepted in 27.VII.2004. 